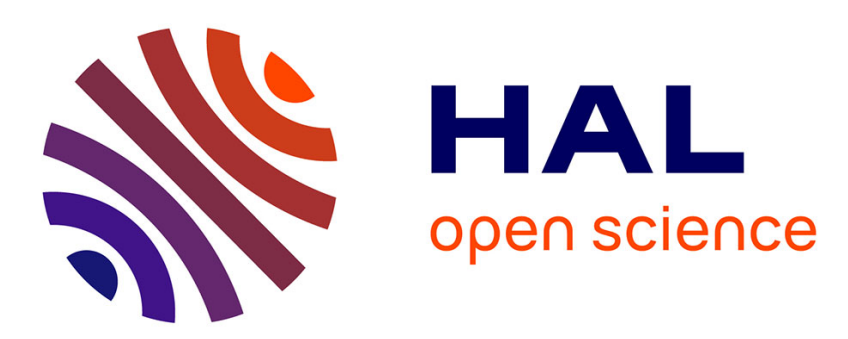

\title{
Ti3 + production under ionizing radiation in aluminoborosilicate glasses studied by EPR spectroscopy
}

Pierre Lombard, Nadège Ollier, Bruno Boizot

\section{To cite this version:}

Pierre Lombard, Nadège Ollier, Bruno Boizot. Ti3+ production under ionizing radiation in aluminoborosilicate glasses studied by EPR spectroscopy. Conference on the Structure of Non-Crystalline Materials (NCM11), Jun 2010, Paris, France. pp.2719-2722, 10.1016/j.jnoncrysol.2010.12.070 . hal00599085

\section{HAL Id: hal-00599085}

https://hal-polytechnique.archives-ouvertes.fr/hal-00599085

Submitted on 8 Jun 2011

HAL is a multi-disciplinary open access archive for the deposit and dissemination of scientific research documents, whether they are published or not. The documents may come from teaching and research institutions in France or abroad, or from public or private research centers.
L'archive ouverte pluridisciplinaire HAL, est destinée au dépôt et à la diffusion de documents scientifiques de niveau recherche, publiés ou non, émanant des établissements d'enseignement et de recherche français ou étrangers, des laboratoires publics ou privés. 


\title{
$\mathrm{Ti}^{3+}$ production under ionizing radiation in aluminoborosilicate glasses by EPR spectroscopy.
}

\author{
P. Lombard ${ }^{1 *}$, N. Ollier ${ }^{1}$, B. Boizot ${ }^{1}$
}

1. Laboratoire des Solides Irradiés, UMR 7642 CEA-CNRS-Ecole Polytechnique Ecole Polytechnique, Route de Saclay, 91128 Palaiseau CEDEX, France

*Corresponding author: pierre.lombard@polytechnique.edu

Tél. : +33 (0) 169334502 - Fax. : +33 (0)1 69334654

\begin{abstract}
Reduction processes under irradiation of $\mathrm{T}^{4+}$ ions in aluminoborosilicate glasses have been studied by EPR spectroscopy at $20 \mathrm{~K}$. Different parameters like the $[\mathrm{Na}] /[\mathrm{Ti}]$ ratio and the integrated dose were analyzed in this work. Simulation of the $\mathrm{Ti}^{3+}$ ion EPR spectra has shown three different $\mathrm{Ti}^{3+}$ environment attributed to one

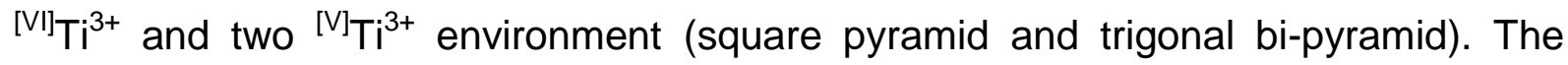

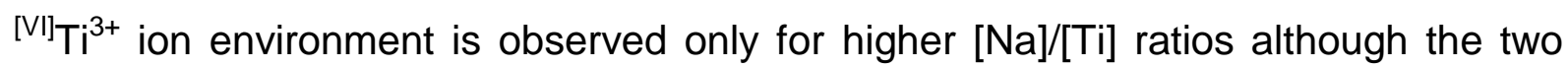
others are observed for all values of the $[\mathrm{Na}] /[\mathrm{Ti}]$ ratio considered.
\end{abstract}

PACS: $76.30 ; 61.43 . \mathrm{Fs} ; 95.75 . \mathrm{Fg}$.

1. Introduction

Reduction processes under ionizing radiation has been observed in glasses for different ions like $\mathrm{Sm}^{3+}[1], \mathrm{Yb}^{3+}[2]$ and $\mathrm{Cr}^{6+}[3]$. In a recent work, we have studied by EPR spectroscopy combined with the simulation of $\mathrm{Ti}^{3+}$ EPR spectra the environment around $\mathrm{Ti}^{3+}$ ions produced under ionizing irradiation in silicate glasses [4]. We have shown that the $\mathrm{Ti}^{3+}$ EPR spectra is the sum of different components attributing to three different environments of $\mathrm{Ti}^{3+}$ ions denoted $s_{l}, s_{\|}$and $s_{\| l}$. The relative proportions between the different $\mathrm{Ti}^{3+}$ sites depend mainly on the $[\mathrm{Na}] /[\mathrm{Ti}]$ ratio and 
therefore on the quantity of alkaline ions available for acting as charge compensator of $\mathrm{Ti}^{3+}$ ions with different coordination numbers. In silicate glasses, $\mathrm{Ti}^{4+}$ ions can be found under four main environments $\left({ }^{[\mathrm{VI}]} \mathrm{Ti}^{4+}\right.$, two ${ }^{[\mathrm{V} \mathrm{Ti}} \mathrm{T}^{4+}$ and $\left.{ }^{[\mathrm{IV}]} \mathrm{Ti}{ }^{4+}\right)[5]$. We proposed to associate $s_{I}$ and $s_{I I I}$ sites with ${ }^{\left[{ }^{[V I}\right]} \mathrm{Ti}^{3+}$ ions and ${ }^{\left[{ }^{[V} \mathrm{T}\right.} i^{3+}$ ions in a square pyramid geometry, respectively. The nature of the $s_{/ /}$site is still in discussion between a ${ }^{\left[V^{l}\right]} \mathrm{Ti}^{3+}$ with an oxygen vacancy and ${ }^{\left[{ }^{[}\right]} \mathrm{Ti}^{3+}$ ions in trigonal bi-pyramid environments.

In the present study, our aim is to apply the method developed for silicate glasses to more complex Ti doped AluminoBoroSilicate (ABS) glass composition. By contrary of silicate glasses, a competition will exist between different ions $\left(\mathrm{Al}^{3+}, \mathrm{B}^{3+}\right.$ and $\left.\mathrm{Ti}^{4+}\right)$ for trapping alkaline ions as charge compensators. This competition could limit the reduction efficiency of $\mathrm{Ti}^{4+}$ and therefore modify the nature of $\mathrm{Ti}^{3+}$ sites produced during ionizing radiation. According to the literature, G. El-Damrawi et al. [6] demonstrate by nuclear magnetic resonance spectroscopy that the $\mathrm{Al}^{3+}$ ions will consume first the alkaline ions. Then, the remaining $\mathrm{Na}^{+}$ions are used either by boron atoms to form $\mathrm{B}^{\mathrm{IV}}$ species or non-bridging oxygen. In this work, we have also to take into account the titanium ions. However, to our knowledge, there is no study of the competition between titanium and others ions for consuming the $\mathrm{Na}^{+}$ions.

\section{Experimental}

The chemical compositions of our ABS glass samples are displayed in Table 1 and prepared by mixing appropriate amounts of analytical reagent grade in an agate mortar with ethanol. The powders were then transferred in a Pt-crucible and placed in an air-oven at $850^{\circ} \mathrm{C}$ for $10 \mathrm{~h}$ to ensure a correct decarbonatation of different carbonate powders $\left(\mathrm{Na}_{2} \mathrm{CO}_{3}\right)$. Then, the melt was heated to $1600{ }^{\circ} \mathrm{C}$ in $3 \mathrm{~h}$ and 
quenched. The obtained samples were cut and manually polished on a Labram HR Mecapol.

One important parameter indicated in Table 1 for ABS glasses is the $(\mathrm{Na} / \mathrm{Ti})^{*}$ ratio defined as following:

$$
\left(\frac{N a}{T i}\right)^{*}=\frac{2\left[\mathrm{Na}_{2} \mathrm{O}\right]-2\left[\mathrm{Al}_{2} \mathrm{O}_{3}\right]-\mathrm{N}_{4}\left[\mathrm{~B}_{2} \mathrm{O}_{3}\right]}{\left[\mathrm{TiO}_{2}\right]}
$$

Where all the brackets denote the quantities of matter (in mol\%) and $N_{4}$ is the ratio of $\mathrm{B}^{\mathrm{IV}}$ to the total $\mathrm{B}_{2} \mathrm{O}_{3}$ amount. We assume for $(\mathrm{Na} / \mathrm{Ti})^{*}$ ratio that the titanium ions trap $\mathrm{Na}^{+}$ions after $\mathrm{Al}^{3+}$ and $\mathrm{B}^{3+}$ ions but before the production of non bridging oxygen. All samples were $\beta$-irradiated with electrons of $2.5 \mathrm{MeV}(10 \mu \mathrm{A})$ and temperature lower than $80^{\circ} \mathrm{C}$ using a Van de Graaff accelerator (Laboratoire des Solides Irradiés, France). Different doses between $3.37 \times 10^{5}$ and $1.68 \times 10^{9}$ Gy were integrated.

X-band $(v=9.490 \mathrm{GHz})$ EPR spectra were recorded at $20 \mathrm{~K}$ using an OXFORD He cryostat with an EMX Bruker EPR spectrometer operating with a microwave power of $0.05 \mathrm{~mW}$. The EPR spectra have been normalized to the receiver gain and to the sample weight. Simulation of $\mathrm{Ti}^{3+}$ EPR spectra were made using the ZFSFIT program developed by G. Morin and D. Bonnin [7]. The least square refinement process between simulated and experimental $\mathrm{Ti}^{3+}$ EPR spectrum gives access to the number and the nature of each $\mathrm{Ti}^{3+}$ sites in $\mathrm{ABS}$ glasses as a function of the integrated dose and glass compositions.

3. Results and discussion

Figure 1 presents the X-band EPR spectra of $\mathrm{Ti}^{3+}$ ions in $\beta$-irradiated ABS glasses with $(\mathrm{Na} / \mathrm{Ti})^{*}$ ratios between 5 and 115 and the spectrum of an undoped sample 
(multiplied by factor 0.5 to improve lisibility). On this last one, the observed spectrum is attributed to defects produced during ionizing radiation. The nature of these defects has been previously studied by EPR spectroscopy in the non doped irradiated ABS glass composition [8]. On the spectra of the doped samples, we observe additional components of the spectrum, located between 3400 and 4000 Gauss and are attributed to $\mathrm{Ti}^{3+}$ ions. The spectrum of the defects is complex but it extends do not overlap the TI3+ spectrum. Thus, hereafter will focus our study on the EPR spectrum of $\mathrm{Ti}^{3+}$ ions. Globally, Figure 1 clearly shows a dependence between the shape of the EPR spectrum and the $(\mathrm{Na} / \mathrm{Ti})^{*}$ ratio. The EPR spectrum of the first sample, B5, is characterized by a positive peak around $g=1.940 \pm 0.003$ with a shoulder at $g=1.964 \pm 0.003$ and a negative peak at $g=1.901 \pm 0.003$. When the $(\mathrm{Na} / \mathrm{Ti})^{*}$ ratio increases to 40 , the intensity of the positive peak at $g=1.940 \pm 0.003$ increases relative to the intensity of the shoulder at $g=1.901 \pm 0.003$. For higher $(\mathrm{Na} / \mathrm{Ti})^{*}$ ratios, an additional EPR line characterized by $g_{\perp}=1.973$ and $g_{/ /}=1.939$ is observed. We can attribute the evolutions of the EPR spectra to the presence of different $\mathrm{Ti}^{3+}$ EPR sites in the irradiated ABS glass EPR spectra. This $\mathrm{Ti}^{3+}$ ions site EPR spectrum appearing only at the higher $(\mathrm{Na} / \mathrm{Ti})^{*}$ ratio was already observed in silicate glasses [4]. It was noted $s_{I}$ and hereafter we will use the same denomination. By contrary, the other components of $\mathrm{Ti}^{3+}$ EPR spectra are different from those observed in our previous work with a $[\mathrm{Na}] /[\mathrm{Ti}]$ ratio less or equal to 40 .

The figure 2 presents the evolution of the EPR spectra of two samples with the lowest (5) and the highest (115) $(\mathrm{Na} / \mathrm{Ti})^{*}$ ratio as a function of the integrated dose. Before irradiation, no $\mathrm{Ti}^{3+}$ EPR lines are observed for all ABS glass compositions studied. At low $(\mathrm{Na} / \mathrm{Ti})^{*}$ ratio (B5 sample) the intensity of the $\mathrm{Ti}^{3+} \mathrm{EPR}$ spectrum increase with the dose without any significant EPR line shape changes. However at 
high $(\mathrm{Na} / \mathrm{Ti})^{*}$ ratio $\left(\mathrm{B} 115\right.$ sample), the $\mathrm{Ti}^{3+} \mathrm{EPR}$ spectrum of the sample irradiated at $3.37 \times 10^{5} \mathrm{~Gy}$ is characterized by one component with $g_{\perp}=1.973$ and $g_{/ /}=1.945$ attributed to the $s_{I} \mathrm{Ti}^{3+}$ site. As a function of the integrated dose, additional $\mathrm{Ti}^{3+} \mathrm{EPR}$ components defined by a positive peak at $g=1.945$ and a broad negative peak at $g$ $=1.890$ are appearing. At higher dose, the relative intensity of the $s_{l}$ EPR spectrum diminishes with respect to the other $\mathrm{Ti}^{3+}$ sites. This change in site proportions could be related to alkaline ions and oxygen migration under irradiation located in charge compensator position of titanium ions [9-12]. The decrease of $s_{l}$ is showing therefore a decrease of the average coordination number around $\mathrm{Ti}^{4+}$ and/or $\mathrm{Ti}^{3+}$ ions at higher doses in ABS glasses.

The simulation of $\mathrm{Ti}^{3+}$ EPR spectra in irradiated Ti doped ABS glasses as a function of $(\mathrm{Na} / \mathrm{Ti})^{*}$ and dose has been performed considering first that the $s_{l}$ EPR spectrum is the same for both silicate and ABS glasses. The second point is that, due to the similarities between the $\mathrm{Ti}^{3+}$ EPR spectra in silicate and ABS glasses, we used the EPR parameters of the sites identified previously $\left(s_{\| /}\right.$and $\left.s_{\| I I}\right)$ as a starting point to refine the EPR parameters of the other $\mathrm{Ti}^{3+}$ sites in ABS glasses. Two other $\mathrm{Ti}^{3+}$ sites $\left(b_{\| I}\right.$ and $\left.b_{I I I}\right)$ were determined in irradiated ABS glasses with parameters given in Table 2. If we consider possible EPR lines broadening with the integrated dose due to dipole-dipole interactions, a linear combination of these three $\mathrm{Ti}^{3+}$ ion sites $\left(s_{l}, b_{l l}\right.$ and $\left.b_{I I I}\right)$ allows us to reproduce the EPR spectra of all irradiated samples of this work. An example of simulation is presented in figure 3 for the B115 sample irradiated at $1.68 \times 10^{9} \mathrm{~Gy}$. The first result associated to this work is that the $s_{\text {/ }}$ site is encountered in both silicate and ABS glass compositions showing therefore the lack of influence of other network formers $\left(\mathrm{B}^{3+}, \mathrm{Al}^{3+}\right)$ on $s_{/}$EPR parameters. According to literature [13, 14], the $s$ / site EPR parameters reveal an octahedral environment around $\mathrm{Ti}^{3+}$ ions. 
By contrary, the presence of boron and aluminum ions in network formers position influences the EPR parameters of $s_{\| /}$and $s_{\| /}$sites leading to $b_{\| /}$and $b_{\| l}$, respectively. These results could therefore show a specific speciation for these $\mathrm{Ti}^{3+}$ environments close to $\mathrm{Al}^{3+}$ and/or $\mathrm{B}^{3+}$ ions.

\section{Conclusion}

We have studied in this work by EPR the environment of $\mathrm{Ti}^{3+}$ ions produced under ionizing radiation in Ti-doped ABS glasses. We conclude to the existence of three different $\mathrm{Ti}^{3+}$ EPR sites, denoted $s_{l}, b_{\| /}$and $b_{\| I}$. The first one, $s_{l}$, is associated to a

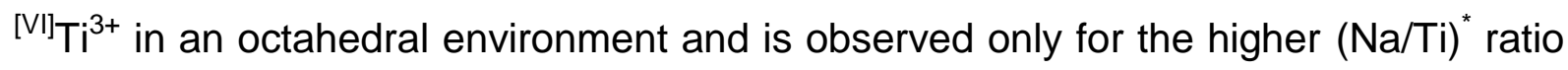
and integrated dose less than $1 \times 10^{9} \mathrm{~Gy}$. The two other $\mathrm{Ti}^{3+}$ sites $b_{I I}$ and $b_{I I I}$, observed for all $(\mathrm{Na} / \mathrm{Ti})^{*}$ ratios, could correspond to $\mathrm{Ti}^{3+}$ ions in fivefold environment by analogy with silicate glasses.

5. Acknowledgements

We sincerely thanks T. Pouthier (LSI, Ecole Polytechnique, France) and V. Metayer (LSI, Ecole Polytechnique, France) for their kind help during irradiation experiments.

6. References

[1] E. Malchukova, B. Boizot, G. Petite, D. Ghaleb. J. of Non_Cryst. Solids 353 (2007) 2397. 
[2] N. Ollier, R. Planchais, B. Boizot. Nucl. Instr. and Meth. in Phys. Res. B 266 (1213) (2008) 2854.

[3] B. Boizot, F. Olivier, G. Petite, D. Ghaleb. Nucl. Instr. and Meth. in Phys. Res. B $266(12-13)(2008) 2966$.

[4] P. Lombard, N. Ollier, B. Boizot (2010) submitted to J. of Non_Cryst. Solids.

[5] F. Farges, G.E. Brown, A. Navrotsky, H. Gan, J. Rehr. Geochim. Cosmochim. Acta 60 (16) (1996) 3039.

[6] G. El-Damrawi, W. Muller-Warmuth, H. Doweidar, I.A. Gohar. Phys. Chem. Of Glasses 34 (1993) 52.

[7] G. Morin, D. Bonnin. J. Mag. Res. 136 (1999) 176.

[8] B. Boizot, G. Petite, D. Ghaleb, G. Calas. Nucl. Instr. and Meth. in Phys. Res. B 141 (1998) 580.

[9] N. Ollier, B. Champagnon, B. Boizot, Y. Guyot, G. Panczer, B. Padlyak. J. of Non_Cryst. Solids 323 (2003) 200.

[10] B. Boizot, N. Ollier, F. Olivier, G. Petite, D. Ghaleb, E. Malchukova. Nucl. Instr. and Meth. in Phys. Res. B 240 (2005) 146.

[11] B. Boizot, G. Petite, D. Ghaleb, N. Pellerin, F. Fayon, B. Reynard, G. Calas.

Nucl. Instr. and Meth. in Phys. Res. B 166-167 (2000) 500.

[12] N. Ollier, B. Boizot, B. Reynard, D. Ghaleb, G. Petite. J. of Nucl. Mat 340 (2-3) (2005) 209.

[13] S. Arafa, F. Assabghy. J. App. Phys. 45 (12) (1974) 5269.

[14] H. Bohm, G. Bayer. J. of Non_Cryst. Solids 31 (1970) 2125. 
Figure captions

Figure 1: EPR spectra of $\beta$-irradiated at $3.10^{7}$ Gy ABS Glasses with $(\mathrm{Na} / \mathrm{Ti})^{*}$ of 0 , 5, 40, 86 and 115 .

Figure 2: Influence of the integrated dose between $3 \times 10^{5}$ and $1.68 \times 10^{9}$ Gy EPR spectra on the EPR spectra of B5 and B115 ABS glass samples.

Figure 3: Simulated and experimental EPR spectra of B115 sample irradiated at $3.10^{7}$ Gy. The simulated EPR spectra of $s_{l}, b_{\mid l}$ and $b_{|l|}$ are also presented in this figure 
Tables

\begin{tabular}{|c|ccccc|c|}
\hline Sample & {$\left[\mathrm{SiO}_{2}\right]$} & {$\left[\mathrm{Na}_{2} \mathrm{O}\right]$} & {$\left[\mathrm{Al}_{2} \mathrm{O}_{3}\right]$} & {$\left[\mathrm{B}_{2} \mathrm{O}_{3}\right]$} & {$\left[\mathrm{TiO}_{2}\right]$} & $(\mathrm{Na} / \mathrm{Ti})^{*}$ \\
\hline $\mathrm{B} 5$ & 64.4 & 13.5 & 4.1 & 17.0 & 1 & 5 \\
$\mathrm{~B} 40$ & 55.2 & 25.8 & 3.5 & 14.6 & 0.9 & 40 \\
$\mathrm{~B} 86$ & 46.4 & 37.6 & 3.0 & 12.3 & 0.7 & 86 \\
$\mathrm{~B} 115$ & 42.2 & 43.3 & 2.7 & 11.2 & 0.6 & 115 \\
\hline
\end{tabular}

Table 1: Ti doped ABS glass sample compositions. All quantities are in mol\%. See text for the definition of the $(\mathrm{Na} / \mathrm{Ti})^{*}$.

\begin{tabular}{|c|ccc|}
\hline Site & $g_{x}$ & $g_{y}$ & $g_{z}$ \\
\hline$s_{I}$ & 1.939 & \multicolumn{2}{|c|}{1.970} \\
$b_{I I}$ & 1.890 & 1.919 & 1.969 \\
$b_{I I I}$ & 1.848 & 1.896 & 1.939 \\
$s_{I I}$ & 1.868 & 1.904 & 1.965 \\
$s_{I I I}$ & 1.763 & 1.863 & 1.936 \\
\hline
\end{tabular}

Table 2: EPR parameters of $\mathrm{Ti}^{3+}$ sites observed in $\beta$-irradiated ABS glasses. The EPR parameters of $s_{/ /}$and $s_{\| I I} \mathrm{Ti}^{3+}$ sites in silicate glasses extracted from [Lombard et al., 2010] are also presented in table 2. 
Figure 1

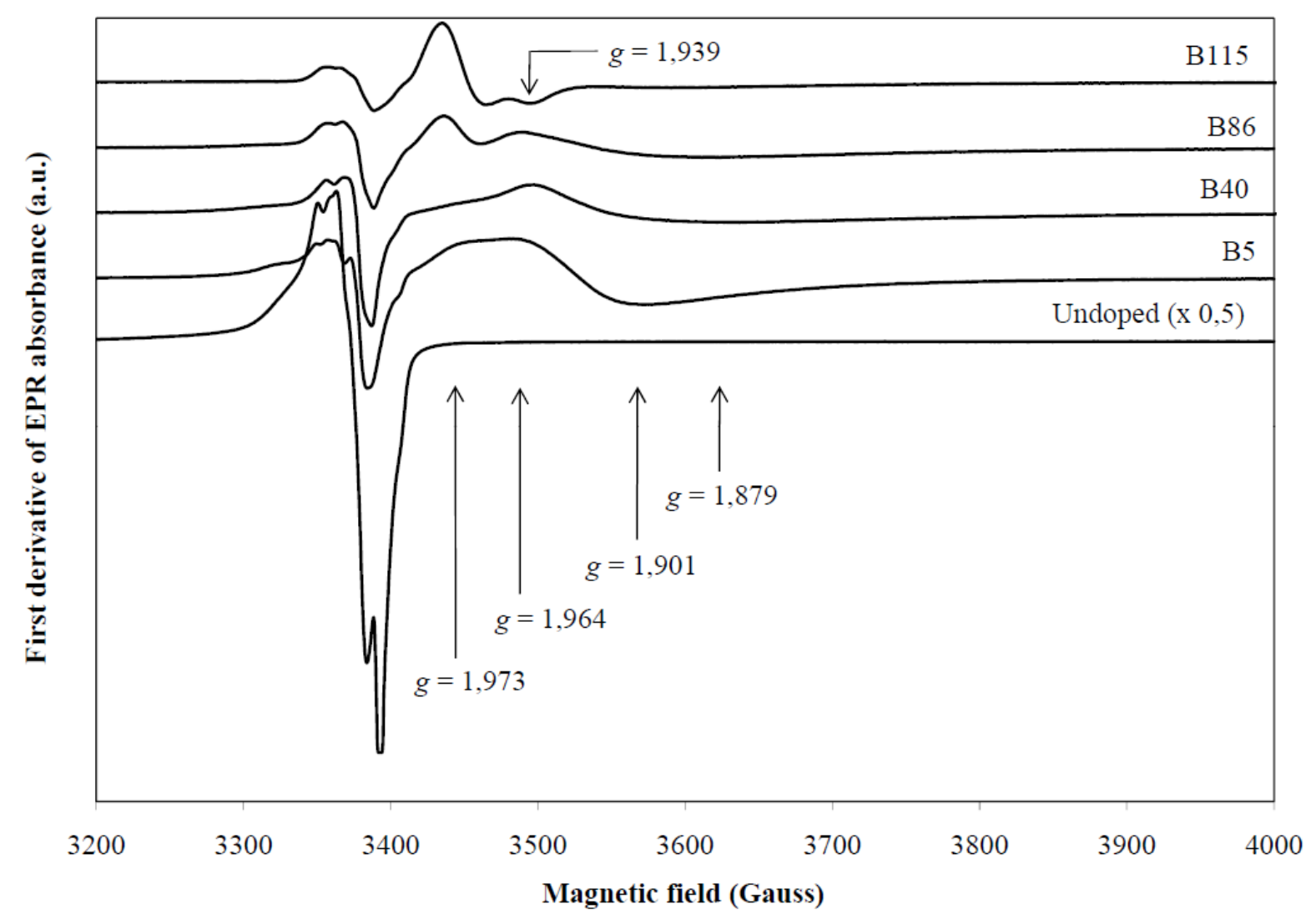


Figure 2
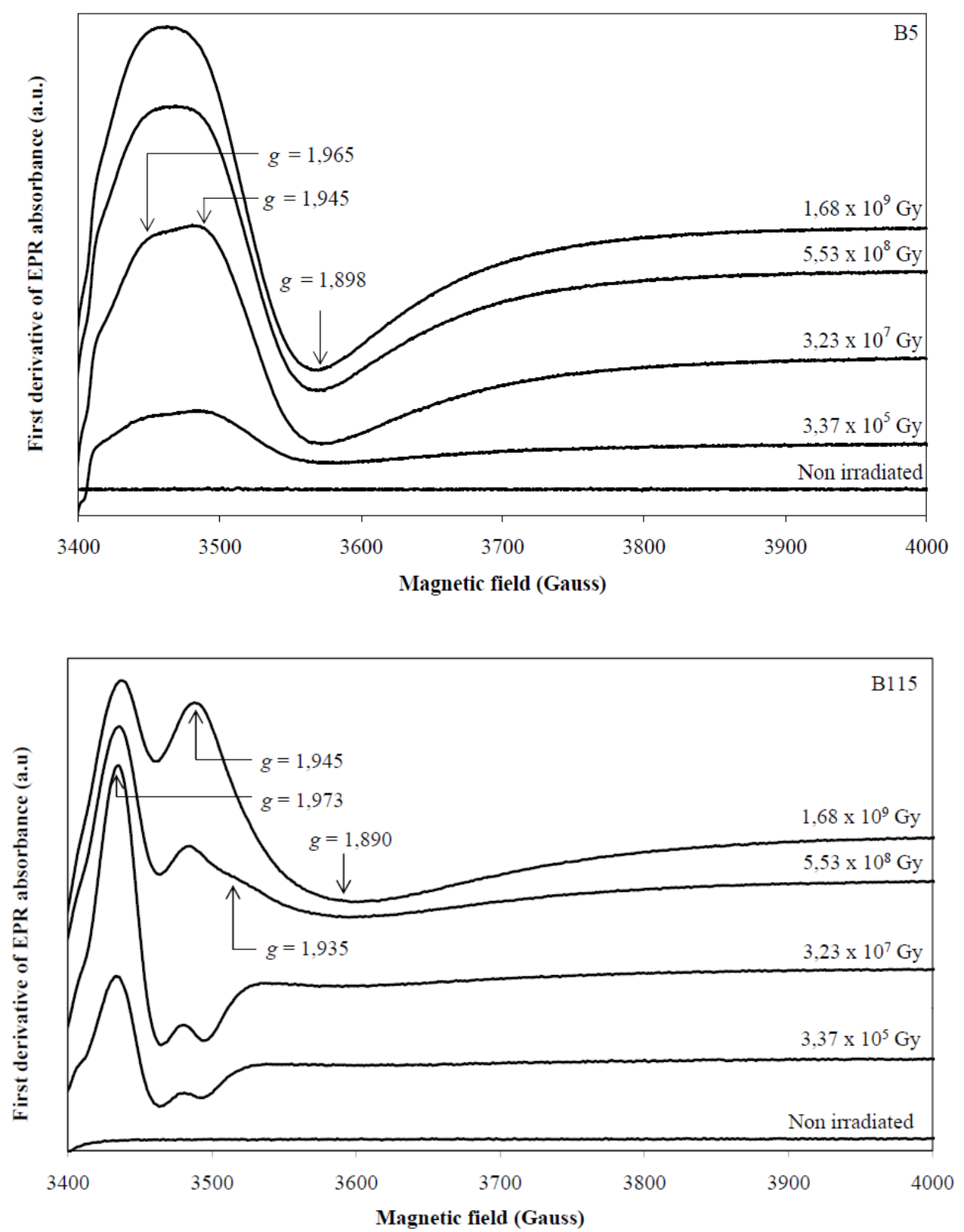
Figure 3

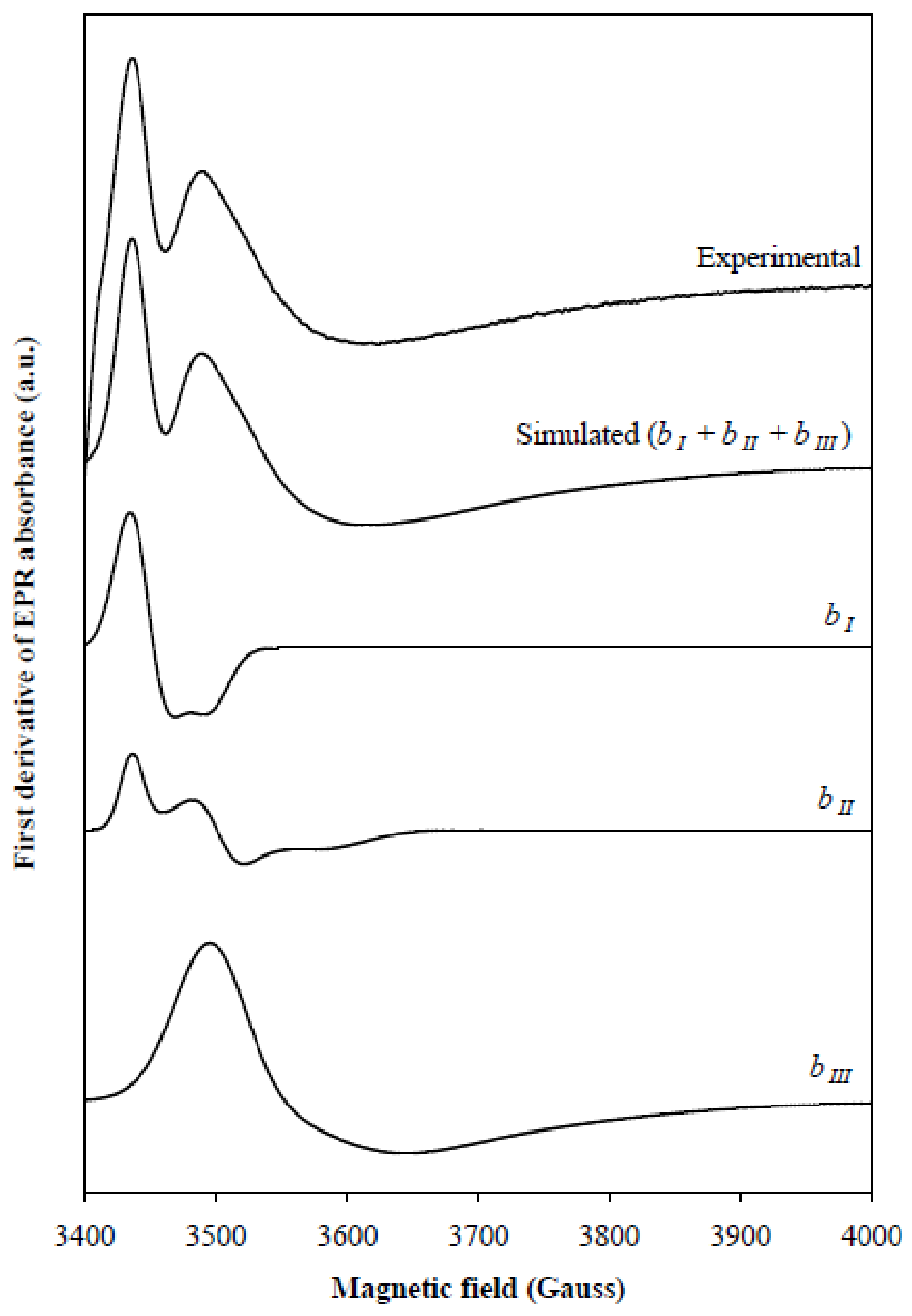

